\title{
THE THERMOHYDRAULIC ANALYSIS OF THE BANDUNG RESEARCH REACTOR CORE WITH PLATE TYPE FUEL ELEMENTS USING THE CFD CODE
}

\author{
Reinaldy Nazar ${ }^{*}$, Sudjatmi KA, K. Kamajaya \\ Center of Applied Nuclear Science and Technology - BATAN Jln. Tamansari No. 71, Bandung, 40123 \\ *E-mail: reinaldynazar@batan.go.id \\ Diterima editor: 20 September 2018 \\ Diperbaiki: 10 Oktober 2018 \\ Disetujui untuk publikasi: 11 Oktober 2018
}

\begin{abstract}
THE THERMOHYDRAULIC ANALYSIS OF THE BANDUNG RESEARCH REACTOR CORE WITH PLATE TYPE FUEL ELEMENTS USING THE CFD CODE. Due to TRIGA fuel elements are no longer produced by General Atomic, it is necessary to find a solution so that the Bandung TRIGA 2000 reactor can still be operated. One solution is to replace the type of fuel elements. Study on using the MTR plate type fuel elements as used in RSG-GAS Serpong has been done for the Bandung TRIGA 2000. Based on the results of the study using CFD computer program, it is found that Bandung TRIGA 2000 with plate type fuel elements cannot be operated up to $2000 \mathrm{~kW}$ power by natural convection cooling mode. Therefore, the reactor must be cooled by forced convection. The analysis using forced convection showed that for cooling flow rate of $50 \mathrm{~kg} / \mathrm{s}$ and various temperatures of $35^{\circ} \mathrm{C}, 35.5{ }^{\circ} \mathrm{C}$ and $36{ }^{\circ} \mathrm{C}$, the surface temperature of the fuel element is between $110.37{ }^{\circ} \mathrm{C}$ and $111.27{ }^{\circ} \mathrm{C}$. Meanwhile, the cooling water temperature in the corresponding position is between $61.03{ }^{\circ} \mathrm{C}$ and $61.95{ }^{\circ} \mathrm{C}$. In this operation condition, the surface temperatures of fuel elements can approach the saturation temperature and nucleat boiling started to occur. Hence, the use of cooling flow rate entering core less than $50 \mathrm{~kg} / \mathrm{s}$ should be avoided. The surface temperature of fuel elements decreased under saturation temperature if cooling flow rate is greater than $65 \mathrm{~kg} / \mathrm{s}$. The surface temperature of fuel elements is achieved at $96.65{ }^{\circ} \mathrm{C}$ and coolant temperature in the corresponding position was $54.38^{\circ} \mathrm{C}$.
\end{abstract}

Keywords: Bandung research reactor, plate type fuel element, thermohydraulic, CFD code

\begin{abstract}
ABSTRAK
ANALISIS TERMOHIDROLIK TERAS REAKTOR RISET BANDUNG BERELEMEN BAKAR TIPE PELAT MENGGUNAKAN PROGRAM CFD. Mengingat tidak diproduksinya lagi elemen bakar TRIGA oleh General Atomic, maka perlu diusahakan suatu solusi agar reaktor TRIGA 2000 Bandung dapat tetap beroperasi. Salah satu solusi adalah dengan melakukan penggantian tipe elemen bakar. Pada studi ini telah dianalisis penggunaan elemen bakar tipe pelat yang sejenis dengan yang digunakan di RSG-GAS Serpong, untuk digunakankan pada teras reaktor TRIGA 2000 Bandung. Berdasarkan hasil penelitian yang telah dilakukan dengan menggunakan program komputer CFD, diketahui bahwa reaktor TRIGA berelemen bakar tipe pelat tidak dapat dioperasikan pada daya $2000 \mathrm{~kW}$ dengan menggunakan moda pendinginan konveksi alamiah seperti yang digunakan saat ini. Untuk kondisi ini, pendinginan dilakukan dengan moda pendinginan konveksi paksa. Hasil analisis konveksi paksa menunjukkan bahwa dengan menggunakan laju alir pendingin pompa $50 \mathrm{~kg} / \mathrm{s}$ dan variasi temperatur pada $35^{\circ} \mathrm{C}, 35,5^{\circ} \mathrm{C}$ dan $36{ }^{\circ} \mathrm{C}$, diperoleh temperatur permukaan pelat elemen bakar antara $110,37{ }^{\circ} \mathrm{C}-111,27{ }^{\circ} \mathrm{C}$ dan temperatur pendinginnya pada posisi terkait antara $61,03{ }^{\circ} \mathrm{C}-61,95{ }^{\circ} \mathrm{C}$. Temperatur permukaan pelat elemen bakar ini mendekati temperatur saturasi dan tentunya telah mulai terjadi pendidihan inti, sehingga penggunaan laju alir pendingin masuk teras reaktor kurang dari $50 \mathrm{~kg} / \mathrm{s}$ perlu dihindari. Temperatur permukaan pelat elemen bakar mulai menurun menjauhi temperatur saturasi jika digunakan laju alir pendingin lebih besar dari $65 \mathrm{~kg} / \mathrm{s}$, dengan temperatur permukaan pelat elemen bakar $96,65^{\circ} \mathrm{C}$ dan temperatur pendinginnya pada posisi terkait $54,38^{\circ} \mathrm{C}$.
\end{abstract}

Kata kunci: Reaktor riset Bandung, elemen bakar tipe pelat, termohidrolik, program CFD

DOI: $10.17146 / \mathrm{tdm} \cdot 2018 \cdot 20.3 \cdot 4626$ 


\section{INTRODUCTION}

Because TRIGA fuel elements are no longer produced by General Atomic, it is necessary to find a solution so that the TRIGA 2000 reactor can be still operated [1,2]. One solution that can be offered related to that problem is by replacing the type of the fuel element, which is using fuel elements produced domestically. This study will examine the use of other types of fuel elements to be applied in the core of the Bandung TRIGA 2000 reactor. The type of fuel element studied in this study is the plate type fuel element as it has been used in the RSG GAS reactor. This solution was chosen because PT INUKI routinely produces RSG-GAS reactor fuel with very satisfying performance [3].

Many research reactors in Europe have used plate type fuel elements. Most of the fuel elements are dispersion fuel elements, where the fissile material is dispersed in the matrix, usually using $\mathrm{Al}$ with $\mathrm{Al}$ alloy cladding. The fissile material used is a fuel element with high enrichment, and usually UOx or UAlx [4].

The research conducted by G.A Mandala from both neutron and thermal hydraulic aspects shows that the Bandung TRIGA 2000 reactor can use plate type fuel elements [5]. Furthermore, the same researcher has proposed a modification of the TRIGA 2000 Bandung reactor core with a plate type fuel element with SRAC (Standard Reactor Analysis Code) software to obtain neutronic and EUREKA parameters for thermal hydraulic analysis [6].

Sudjatmi et al. conducted a thermal analysis of the TRIGA reactor core natural convection using plate type fuel elements. The calculation is done using the Coolod-N2 program. The thermal hydraulic analysis calculation was carried out at $2000 \mathrm{~kW}$ using a core composition with 16 fuel elements, 4 control elements and one irradiation facility, in a steady state natural convection cooling mode, and reactor power input data varied at various power levels. The results showed that the TRIGA reactor with elemental fuel plate did not meet the safety margin of the thermal hydraulic aspect when operated at $2000 \mathrm{~kW}$. The reactor is only able to operate at $600 \mathrm{~kW}$. In order for the reactor to be operated with a power higher than $600 \mathrm{~kW}$, it is recommended to use cooling with forced convection mode [7].

The results of numerical simulations carried out by Subekti et al on the plate type fuel element for the RSG GAS research reactor through the analysis of porous media and non-porous porous media using CFD Code have obtained temperature distribution and flow rate on the fuel element [8]. The calculation results show that the CFD program has very accurate validation. Therefore, this study will conduct thermal analysis of the Bandung TRIGA 2000 fueled plate type with CFD program. Since the calculation will use a different core configuration of the RSG-GAS reactor, therefore new modeling and CFD calculations must be conducted. In this research activity, it is expected to obtain a valid thermal hydraulic parameter characteristic from the Bandung TRIGA 2000 reactor core with a plate type fuel element.

In the design of the new TRIGA reactor core or modified TRIGA reactor core in addition to neutronic factors, thermal hydraulic factors are also very important to be considered. In this paper, the results of thermal hydraulic analysis of TRIGA 2000 reactor core with plate type fuel element and forced convection cooling system are presented. Calculations were carried out using a CFD program, a reactor model with $2000 \mathrm{~kW}$ power, the number of 16 fuel elements, 4 control elements and 5 irradiation facilities [1]. The results of this study are expected to be taken into consideration regarding the level of power used in the TRIGA reactor conversion operation safety and safely.

The results of this study will be useful in carrying out design details that must be done in order to convert fuel elements from the rod type to the plate type. In order to get the details of the core hydraulic system design and safety systems, the results of this study are required.

\section{THEORY}

The TRIGA reactor simulation with plate type fuel elements is done by making 3D images of all reactor systems such as a reactor tank, a reactor core, fuel elements, a reflector, primary 
cooling pipes in the reactor tank, and irradiated facility components around the core. In order to obtain the right and complete reactor model, detailed and accurate reactor geometry is needed.

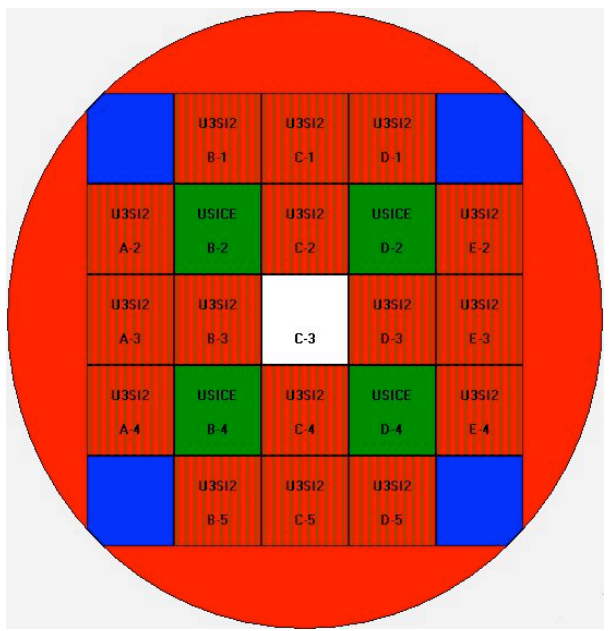

- Four control elements: $\operatorname{Ag}(85-\mathrm{w} \%)$ $\operatorname{In}(10-\mathrm{w} \%)-\mathrm{Cd}(5-\mathrm{w} \%)$;

- Control element position: B2, D2, B4, D4;

- Four IPs (A1, E1, A5, E5);

- One CIP (C3);

- Reflector: Be;

- Fuel elements $\mathrm{U}_{3} \mathrm{Si}_{2}-\mathrm{Al}$ (FE: $250 \mathrm{~g}$ U235, CE:178.6 g-U235, an enrichment $19.75 \mathrm{w} \% \mathrm{U}-235$ ).

Figure 1. Model of the TRIGA reactor core reviewed.

The core of the Bandung TRIGA 2000 reactor studied was the core with a 5 x 5 matrix configuration, so that there were 25 positions, consisting of 5 irradiation positions, where one irradiation position was in the center of the core and four other positions were at each corner of the core, 16 positions for the fuel element, and 4 positions for control elements, as shown in Figure 1.

Each fuel element consists of 21 fuel element plates, and each control element consists of 15 fuel element plates flanked by absorbers. The dimensions of the fuel element cross section and control elements can be seen in Figure 2.

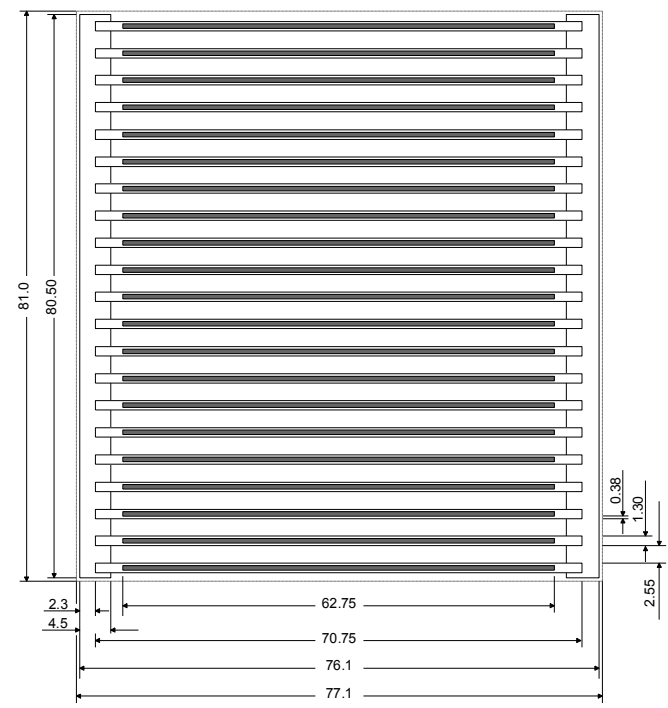

a

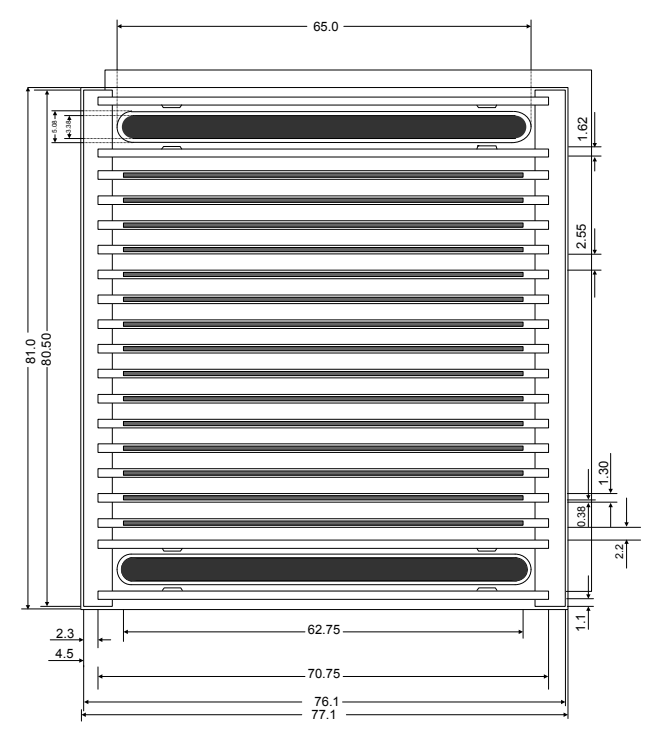

b

Figure 2. Section dimensions of the fuel element (a) and control elements (b) $[9,10,11]$.

The fuel element used was U3Si2-Al with Uranium density of 2.96 grams/cc, the absorbent material was Ag-In-Cd, the fuel element cladding and the control element were AlMg2, and the absorbent cladding was Ag-In-Cd. The fuel element and control elements dimensions are the same as the fuel elements and control elements used in the Serpong RSG-GAS. See Table 1 and Figure 3 . 
Table 1. Geometry data and fuel element specifications $[3,9]$

\begin{tabular}{ll}
\hline \multicolumn{1}{c}{ PARAMETER } & VA \\
\hline I. Dimensions of fuel element and control element & \\
1. Core grid for equipments & 81.0 \\
a. Length (mm) & 77.10 \\
b. Width (mm) & 868.5 \\
c. Height (mm) & 62.75 \\
2. Plate & 1.30 \\
a. Length (mm) & 600 \\
b. Width (mm) & \\
c. Height (mm) & 62.75 \\
3. Fuel element & 0.54 \\
a. Length (mm) & 600 \\
b. Width (mm) & 2.55 \\
c. Height (mm) & 0.38 \\
4. Gap width between plates (cooling channel) (mm) \\
5. Thickness of fuel element cladding (mm) \\
6. Absorbent thickness (mm)
\end{tabular}

\section{Material Specification}
1. Casings and plates material
2. Fuel
$\mathrm{AlMg} 2$
3. Enrichment U-235(w/o)
$\mathrm{U}_{3} \mathrm{Si}_{2}-\mathrm{Al}$
4. Density of uranium in fuel $\left(\mathrm{g} / \mathrm{cm}^{3}\right)$
$19.75 \%$
5. Amount of U-235 per fuel element (gram)
2.96
250
6. Amount of U-235 per control element (gram)
178.6
4. Absorbent material
Ag-In-Cd
5. Absorbent cladding material
Stainless steel
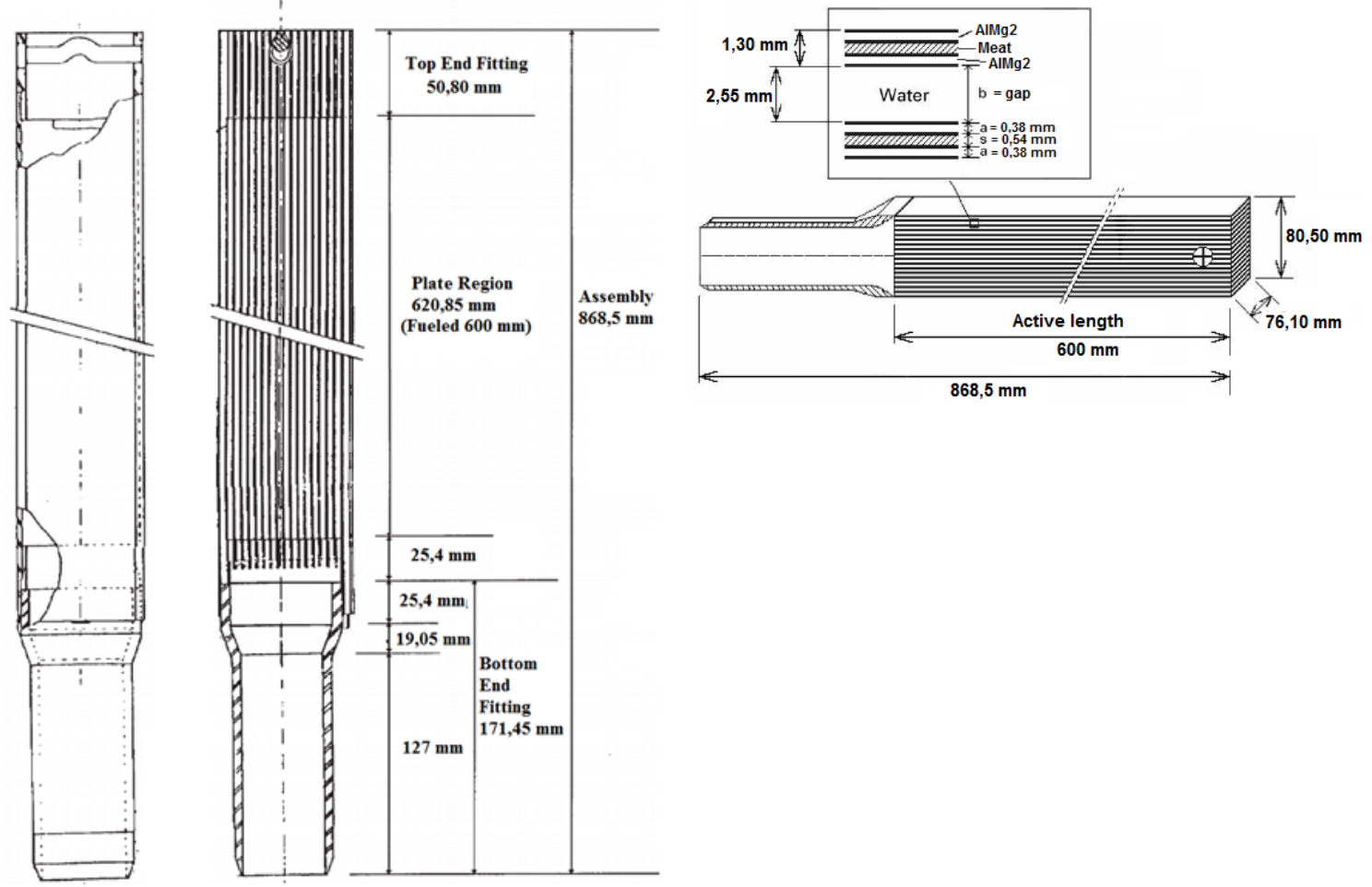

Figure 3. A plate fuel element dimension.

The results of neutron studies conducted by other researchers have obtained the power distribution of each fuel element plate. This power data is used as one of the input data in calculating the thermal parameters of the reactor core, such as the surface temperature of each fuel 
plate, the temperature of the cooling water in the core, and other thermal parameters on the value of the cooling flow rate of the various primary pumps. The power data for each fuel element plate used is stated in Table 2 and Figure 4.

Table 2. Power $(\mathrm{kW})$ of each fuel element plate.

\begin{tabular}{|c|c|c|c|c|c|c|c|c|c|c|c|c|c|c|c|c|c|c|c|c|c|c|}
\hline \multicolumn{22}{|c|}{ POWER (kW) } & \multirow{2}{*}{$\begin{array}{c}\text { TOTAL } \\
\text { (kW) }\end{array}$} \\
\hline PLATE & 1 & 2 & 3 & 4 & 5 & 6 & 7 & 8 & 9 & 10 & 11 & 12 & 13 & 14 & 15 & 16 & 17 & 18 & 19 & 20 & 21 & \\
\hline B-1 & 6.5091 & 5.7115 & 5.1623 & 4.8291 & 4.5935 & 4.4329 & 4.3217 & 4.2478 & 4.2187 & 4.2214 & \begin{tabular}{|l|l|}
4.2118 \\
\end{tabular} & 4.2295 & 4.2525 & 4.2912 & 4.3370 & 4.3608 & 4.3882 & 4.4272 & 4.4724 & 4.5103 & 4.5654 & 6.2943 \\
\hline E-1 & 0 & 0 & 0 & 0 & 0 & 0 & 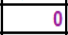 & 0 & 0 & 0 & 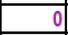 & 0 & 0 & 0 & 7 & 极 & 0 & 0 & 0 & $\sqrt{-1}$ & & \\
\hline A-2 & 4.2654 & 4.0704 & 3.9813 & 3.9390 & 3.9438 & 3.9707 & 4.0243 & 4.0533 & 4.1253 & 4.2013 & \begin{tabular}{|l}
4.2712 \\
\end{tabular} & 4.3581 & 4.4094 & 4.4799 & 4.5833 & 4.6685 & 4.7975 & 9350 & 5.1199 & 5.3680 & 5.7789 & 3.3446 \\
\hline B-2 & 0 & 0 & 0 & 5.8088 & 5.4684 & 5.2372 & 5.1097 & 171 & 4.9896 & 4.9969 & 5.0318 & 5.0675 & 5.1751 & 2638 & 5.4667 & 5.7080 & 6.0415 & 6.5777 & & & & 598 \\
\hline E-2 & 5.8641 & 5.4573 & 5.1801 & 4.9841 & 4.8530 & 4.7337 & 4.6671 & 4.5757 & 4.5111 & 4.4315 & \begin{tabular}{|l|l|}
4.3743 \\
\end{tabular} & 4.2949 & 4.2413 & 4.1838 & 4.1366 & 4.0878 & 4.0924 & 4.1023 & \begin{tabular}{|l}
4.1742 \\
\end{tabular} & 4.2943 & 4.5484 & 879 \\
\hline$A-3$ & 4.5347 & 4.2945 & 4.1660 & 4.1050 & 4.0669 & 4.0750 & 4.1051 & 4.1300 & 4.1548 & 4.1783 & 4.2300 & 4.2841 & 4.3221 & 4.3772 & 4.4231 & 4.4753 & 4.5202 & 4.5923 & 4.6534 & 4.7245 & 4.8074 & .2201 \\
\hline B-3 & 4.8745 & 4.8943 & \begin{tabular}{|l|l|}
4.9144 \\
\end{tabular} & \begin{tabular}{|l|l|}
4.9747 \\
\end{tabular} & 4.9725 & 4.9986 & \begin{tabular}{|l|l|}
5.0492 \\
\end{tabular} & 5.0857 & 5.1438 & 5.2099 & \begin{tabular}{|l|l|}
5.2686 \\
\end{tabular} & 5.3739 & 5.5009 & 5.6690 & \begin{tabular}{|l|l|}
5.8863 \\
\end{tabular} & 6.1640 & 6.5834 & 7.0964 & 7.8379 & \begin{tabular}{|l|}
8.8727 \\
\end{tabular} & \begin{tabular}{|l|}
10.4148 \\
\end{tabular} & 124.7852 \\
\hline$C-3$ & 0 & 0 & 0 & 0 & 0 & 0 & 0 & 0 & 0 & 0 & $\pi$ & 0 & 0 & & 0 & 0 & & & 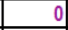 & & & \\
\hline$D-3$ & 10.4662 & 8.9038 & 7.9005 & 7.1618 & 6.6107 & 6.2436 & 5.9770 & 5.7560 & 5.6018 & 5.4710 & \begin{tabular}{|l|l|}
5.3315 \\
\end{tabular} & 5.2787 & 5.2003 & 5.1364 & 5.1097 & 5.0501 & 5.0458 & 5.0070 & 5.0037 & 4.9642 & 4.9210 & \begin{tabular}{|l|l|}
126.1407 \\
\end{tabular} \\
\hline$E-3$ & 4.8512 & 4.7991 & 4.7151 & 4.6810 & 4.6337 & 4.5769 & 4.5130 & 4.4662 & 4.4110 & 4.3643 & 4.3164 & 4.2781 & 4.2602 & 4.2336 & 4.2180 & 4.2293 & 4.2237 & 4.2824 & 4.3714 & 4.5361 & 4.8182 & 3.7788 \\
\hline$A-5$ & of & U & 0 & 0 & 0 & 0 & 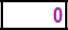 & 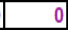 & 0 & 0 & 0 & 0 & 0 & 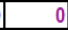 & 0 & 0 & 0 & 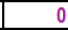 & 0 & 0 & 0 & 0 \\
\hline B-5 & 6.7290 & \begin{tabular}{|l|l|}
5.9127 \\
\end{tabular} & \begin{tabular}{|l|l|}
5.3443 \\
\end{tabular} & 4.9524 & 4.7095 & 4.5419 & 4.4661 & \begin{tabular}{|l|l|}
4.3844 \\
\end{tabular} & 4.3567 & 4.3324 & \begin{tabular}{|l|l|}
4.3426 \\
\end{tabular} & 4.3528 & 4.3827 & 4.4332 & 4.4692 & 4.4882 & 4.4866 & 4.5430 & 4.5839 & 4.6016 & 4.6706 & 99.0838 \\
\hline C-5 & 4.6994 & 4.7159 & \begin{tabular}{|l|l|}
4.7144 \\
\end{tabular} & 4.7226 & 4.7031 & 4.7114 & 4.7181 & 4.6975 & 4.7253 & 4.7149 & 4.7019 & 4.7062 & 4.7022 & 4.7159 & 4.7074 & 4.6942 & 4.6943 & 4.6721 & 4.6753 & 4.6708 & 4.6907 & 98.7537 \\
\hline D-5 & 4.6694 & 4.6182 & 4.5658 & \begin{tabular}{|l|l|}
4.5314 \\
\end{tabular} & 4.5052 & 4.4759 & 4.4437 & 4.4353 & 4.3860 & 4.3590 & \begin{tabular}{|l|l|}
4.3381 \\
\end{tabular} & 4.3215 & 4.3622 & 4.3888 & \begin{tabular}{|l|l|}
4.4867 \\
\end{tabular} & \begin{tabular}{|l|l|}
4.5768 \\
\end{tabular} & 4.7487 & \begin{tabular}{|l|l|}
5.0124 \\
\end{tabular} & 5.3989 & 5.9236 & 6.7762 & 99.3239 \\
\hline E-5 & 0 & 0 & 0 & 0 & 0 & 0 & 0 & 0 & 0 & 0 & 0 & 0 & 0 & 0 & 0 & 0 & 0 & 0 & 0 & 0 & $\underline{0}$ & \\
\hline & & & & & & & & & & & & & & & & & & & & & TOTAL & \\
\hline
\end{tabular}

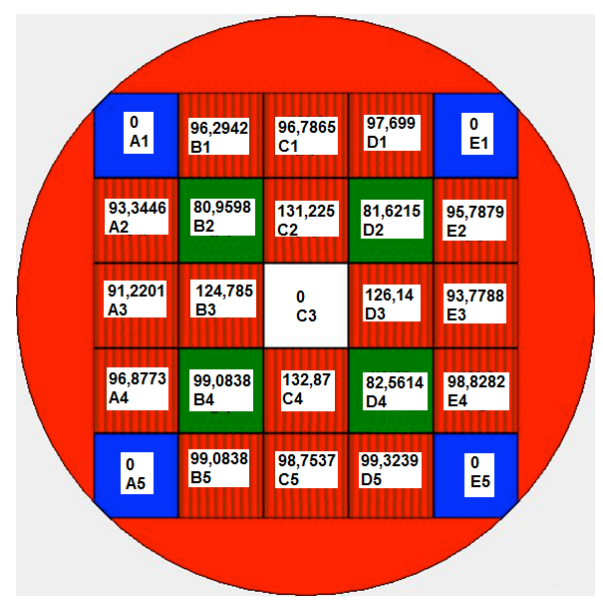

Figure 4. Power data on each fuel element.

\section{METHODOLOGY}

The 3D simulations of a TRIGA reactor with plate type fuel elements and thermal hydraulic core calculations is done using a computational of fluid dynamic (CFD) computer program [8]. The type of CFD computer program used in this study is FLUENT software, where the FLUENT program works through the completion of flow distribution equations, turbulent equations, and energy equations. In this turbulent equation, the viscosity equation of the model k-epsilon, komega, Reynolds Stress, or Large Eddy Simulation (LES) is used.

The FLUENT program calculates flow distribution equations, turbulent equations, and energy equations using a finite volume method, where the model domain that is reviewed is divided into discreteization volume sets. Differential equations are integrated into discretization volumes into algebraic equations as general equations for mass conservation, momentum equations, and energy equations. This conservation equation is very dependent on fluid density, cooling flow area, 
stress tensor, and volume. The term conservation equation is solved by the continuity equation, the momentum equation which refers to the Navier-Stokes equation. The analytical solution to the Navier-Stokes equation applies only to simple flows such as sub-channel flow conditions where ideal conditions apply. The energy conservation equation calculates energy based on the laws of thermodynamics.

Considering the calculation carried out by the FLUENT program refers to the continuity equation, momentum equation and energy balance in the discretization volume that follows the geometry of the fuel element, the determination of the size and volume of the control volume will determine the accuracy of completion. Completion of energy and flow balance is carried out numerically based on predetermined boundary conditions.

The FLUENT calculation includes producing a surface temperature distribution of the fuel element plate, coolant temperature, in detail in a certain interior shape where accuracy is largely determined by the modeling process.

\section{RESULTS AND DISCUSSION}

Using the GAMBIT processor from the FLUENT program a TRIGA reactor model has been made with a plate type fuel element. This reactor model has a core with a 5 x 5 matrix configuration, where there are 25 positions, consisting of 5 irradiation positions, 16 fuel element positions, and 4 control element positions. Each fuel element consists of 21 fuel element plates, and each control element consists of 15 fuel element plates flanked by absorbers. The reactor model reviewed can be seen in Figure 5

Furthermore, temperature data in the core is shown for the value of the primary cooling flow rate of the pump whose value varies, and the temperature of the primary cooling water entering the core varies from $35^{\circ} \mathrm{C}, 35.5^{\circ} \mathrm{C}$ and $36{ }^{\circ} \mathrm{C}$. To simplify the analysis, the surface temperature of the fuel element and the cooling plate is observed at the fuel element plate, which has maximum power, namely plate number 21 on the fuel element of the $\mathrm{C} 4$ position.
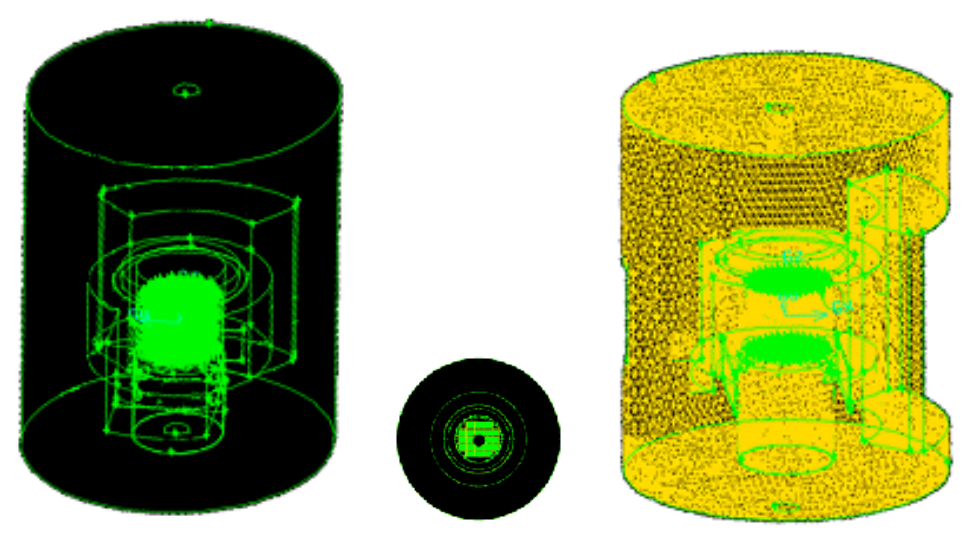

Figure 5. Geometry of the TRIGA reactor model studied and the shape of the grid. 


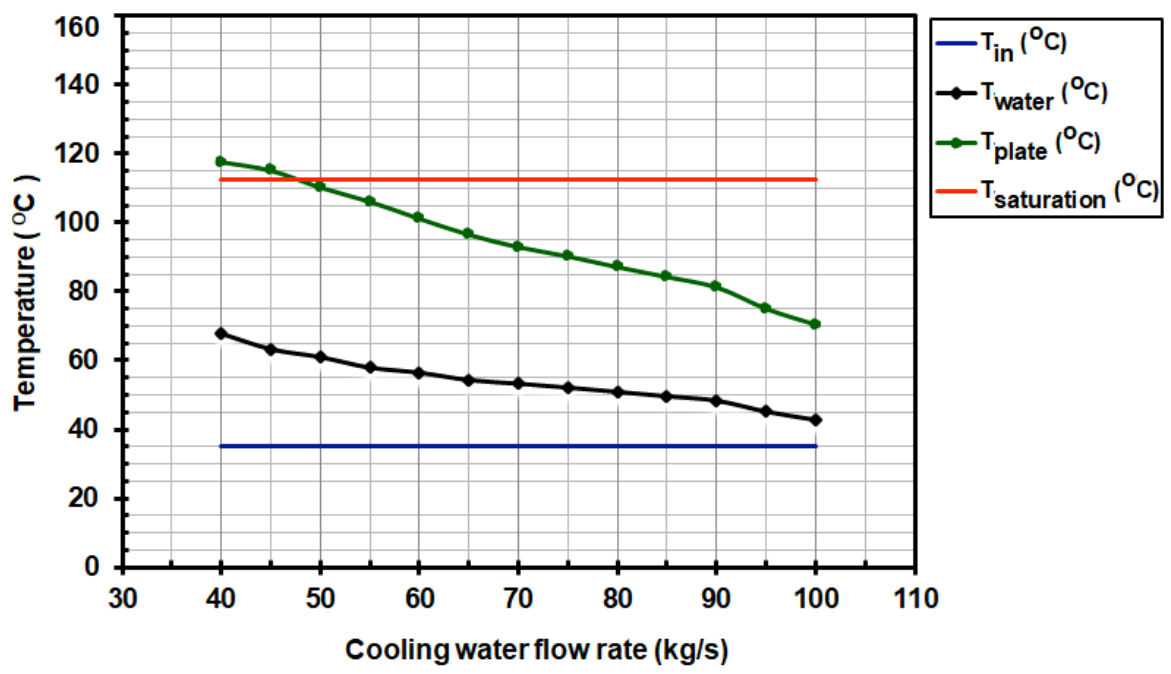

Figure 6. Maximum core temperature of the primary cooling water flow rate from the pump at the cooling temperature that enters the core is $35^{\circ} \mathrm{C}$.

Figure 6 shows the calculation results on the hottest channel, the characteristics of the cooling temperature and the surface of plate number 21 on the fuel element position $\mathrm{C} 4$ as the hottest plate in the core when the cooling flow rate is $40 \mathrm{~kg} / \mathrm{s}, 45 \mathrm{~kg} / \mathrm{s}, 50 \mathrm{~kg} / \mathrm{s}, 55 \mathrm{~kg} / \mathrm{s}, 60 \mathrm{~kg} / \mathrm{s}, 65$ $\mathrm{kg} / \mathrm{s}, 70 \mathrm{~kg} / \mathrm{s}, 75 \mathrm{~kg} / \mathrm{s}, 80 \mathrm{~kg} / \mathrm{s}, 85 \mathrm{~kg} / \mathrm{s}, 90 \mathrm{~kg} / \mathrm{s}, 95 \mathrm{~kg} / \mathrm{s}$, and $100 \mathrm{~kg} / \mathrm{s}$, for temperatures of primary cooling water enters the reactor core by $35^{\circ} \mathrm{C}$. The calculation results show that at a cooling flow rate of $50 \mathrm{~kg} / \mathrm{s}$, it is known that the surface temperature of the fuel element plate is $110.37^{\circ} \mathrm{C}$ and the cooling water temperature is $61.03{ }^{\circ} \mathrm{C}$ in the related position. The surface temperature of the fuel element plate almost reaches a saturation temperature of $112.4{ }^{\circ} \mathrm{C}$. This indicates that nucleate boiling has begun. Thus it can be said that the operation of the TRIGA reactor with plate type fuel cannot be operated by natural convection cooling mode but by forced convection mode. This is in accordance with the results of Sudjatmi et al. [7]. In this condition the temperature of the fuel plate surface temperature approaches the saturation temperature and of course this nucleate boiling has begun, so that the use of the cooling flow rate in the reactor core is $50 \mathrm{~kg} / \mathrm{s}$ insufficient.

Based on Table 3, the operation of the TRIGA reactors with plate fuel elements will be secure and safe when operated at the flow rate of the cooler above $65 \mathrm{~kg} / \mathrm{s}$. The cooling value of the reactor core with a coolant flow rate of $65 \mathrm{~kg} / \mathrm{s}$ is an effective value of $80 \%$ of the amount of coolant pumped to the reactor core. In order to obtain a coolant flow rate of $65 \mathrm{~kg} / \mathrm{s}$ to cool the reactor core, the cooling pump needs to pump the cooling water to the reactor core with a flow rate of $81.25 \mathrm{~kg} / \mathrm{s}$.

Table 3. The reactor core temperature when the cooling temperature enters the reactor at $35^{\circ} \mathrm{C}$.

\begin{tabular}{|c|c|c|c|c|c|}
\hline NO & $\begin{array}{c}\text { FLOW RA TE } \\
(\mathrm{kg} / \mathrm{s})\end{array}$ & $\begin{array}{c}\mathrm{T}_{\text {in }} \\
\left({ }^{\circ} \mathrm{C}\right)\end{array}$ & $\begin{array}{c}\mathrm{T}_{\text {water }} \\
\left({ }^{\circ} \mathrm{C}\right)\end{array}$ & $\begin{array}{c}\mathrm{T}_{\text {plate }} \\
\left({ }^{\circ} \mathrm{C}\right)\end{array}$ & $\begin{array}{c}\mathrm{T}_{\text {saturation }} \\
\left({ }^{\circ} \mathrm{C}\right)\end{array}$ \\
\hline 1 & 40 & 35 & 67.86 & 117.80 & 112.40 \\
\hline 3 & 45 & 35 & 63.34 & 115.30 & 112.40 \\
\hline 5 & 50 & 35 & 61.03 & 110.40 & 112.40 \\
\hline 6 & 55 & 35 & 57.99 & 106.30 & 112.40 \\
\hline 7 & 60 & 35 & 56.53 & 101.30 & 112.40 \\
\hline 8 & 65 & 35 & 54.38 & 96.65 & 112.40 \\
\hline 9 & 70 & 35 & 53.35 & 93.04 & 112.40 \\
\hline 10 & 75 & 35 & 52.21 & 90.35 & 112.40 \\
\hline 11 & 80 & 35 & 50.95 & 87.23 & 112.40 \\
\hline 12 & 85 & 35 & 49.68 & 84.35 & 112.40 \\
\hline 13 & 90 & 35 & 48.42 & 81.34 & 112.40 \\
\hline 14 & 95 & 35 & 45.22 & 75.13 & 112.40 \\
\hline 15 & 100 & 35 & 42.83 & 70.51 & 112.40 \\
\hline
\end{tabular}




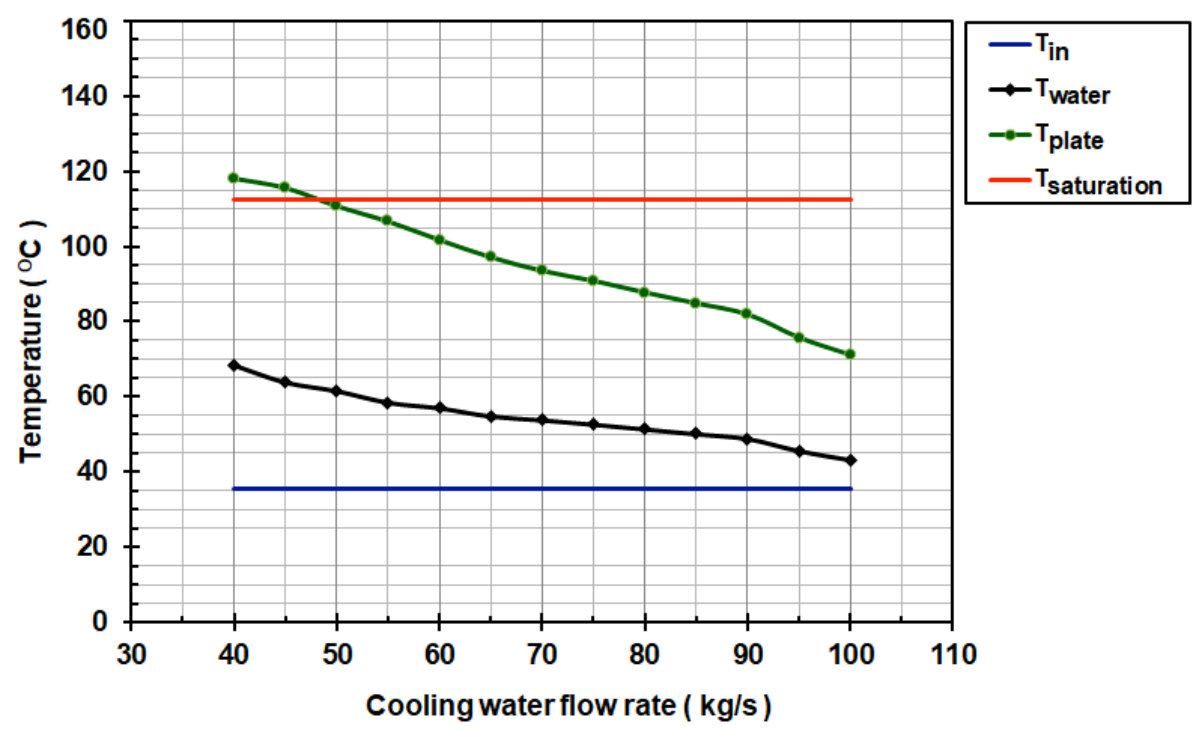

Figure 7. Maximum core temperature of the primary cooling water flow rate from the pump at the cooling temperature that enters the core at $35.5^{\circ} \mathrm{C}$.

Figure 7 shows the calculation results on the hottest channel, the characteristics of the cooling temperature and the surface of plate number 21 on the fuel element position $\mathrm{C} 4$ as the hottest plate in the core when the cooling flow rate is $40 \mathrm{~kg} / \mathrm{s}, 45 \mathrm{~kg} / \mathrm{s}, 50 \mathrm{~kg} / \mathrm{s}, 55 \mathrm{~kg} / \mathrm{s}, 60 \mathrm{~kg} / \mathrm{s}, 65$ $\mathrm{kg} / \mathrm{s}, 70 \mathrm{~kg} / \mathrm{s}, 75 \mathrm{~kg} / \mathrm{s}, 80 \mathrm{~kg} / \mathrm{s}, 85 \mathrm{~kg} / \mathrm{s}, 90 \mathrm{~kg} / \mathrm{s}, 95 \mathrm{~kg} / \mathrm{s}$, and $100 \mathrm{~kg} / \mathrm{s}$, for temperatures of primary cooling water enters the reactor core by $35{ }^{\circ} \mathrm{C}$. The calculation results show that at a cooling flow rate of $50 \mathrm{~kg} / \mathrm{s}$, it is known that the surface temperature of the fuel element plate is $110.82{ }^{\circ} \mathrm{C}$ and the cooling water temperature is $61.49{ }^{\circ} \mathrm{C}$ in the related position. The surface temperature of the fuel element plate almost reaches a saturation temperature of $112.4{ }^{\circ} \mathrm{C}$. This shows that nucleate boiling has also begun, so that the cooling flow rate in the reactor core is $50 \mathrm{~kg} / \mathrm{s}$, insufficient.

Figure 8 shows the calculation results on the hottest channel, the characteristics of the cooling temperature and the surface of plate number 21 on the fuel element position $\mathrm{C} 4$ as the hottest plate in the core when the cooling flow rate is $40 \mathrm{~kg} / \mathrm{s}, 45 \mathrm{~kg} / \mathrm{s}, 50 \mathrm{~kg} / \mathrm{s}, 55 \mathrm{~kg} / \mathrm{s}, 60 \mathrm{~kg} / \mathrm{s}, 65$ $\mathrm{kg} / \mathrm{s}, 70 \mathrm{~kg} / \mathrm{s}, 75 \mathrm{~kg} / \mathrm{s}, 80 \mathrm{~kg} / \mathrm{s}, 85 \mathrm{~kg} / \mathrm{s}, 90 \mathrm{~kg} / \mathrm{s}, 95 \mathrm{~kg} / \mathrm{s}$, and $100 \mathrm{~kg} / \mathrm{s}$, for temperatures primary cooling water enters the reactor core by $35{ }^{\circ} \mathrm{C}$. The calculation results show that at a cooling flow rate of $50 \mathrm{~kg} / \mathrm{s}$ it is known that the surface temperature of the fuel element plate is $111.27^{\circ} \mathrm{C}$ and the cooling water temperature is $61.95{ }^{\circ} \mathrm{C}$ in the related position. The same as the results shown in Figures 6 and 7, the surface temperature of the fuel element plate almost reaches a saturation temperature of $112.4{ }^{\circ} \mathrm{C}$. This shows that nucleate boiling has also begun, so that the cooling flow rate in the reactor core is $50 \mathrm{~kg} / \mathrm{s}$, insufficient. 


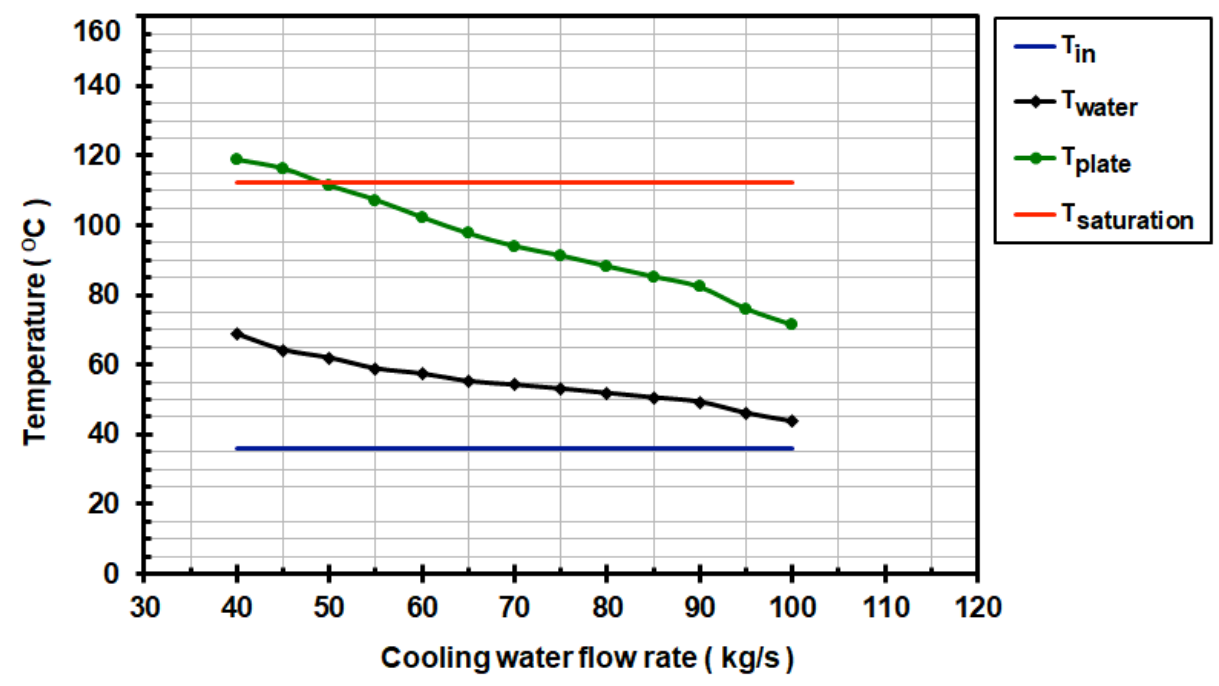

Figure 8. Maximum core temperature of the primary cooling water flow rate from the pump at the cooling temperature that enters the core at $36{ }^{\circ} \mathrm{C}$.

\section{CONCLUSION}

Based on the analysis results that have been carried out using a CFD computer program, it is known that the TRIGA reactor with a plate type fuel element cannot be operated at $2000 \mathrm{~kW}$ with natural convection cooling mode. Therefore it is necessary to do by the forced convection cooling mode. When the cooling flow rate from the pump is $50 \mathrm{~kg} / \mathrm{s}$ and the temperature of the cooling water varies from $35{ }^{\circ} \mathrm{C}, 35.5^{\circ} \mathrm{C}$ and $36{ }^{\circ} \mathrm{C}$, the surface temperature of the fuel element plate is between $110.37{ }^{\circ} \mathrm{C}$ and $111.27{ }^{\circ} \mathrm{C}$ and the cooling temperature at the corresponding position between $61.03{ }^{\circ} \mathrm{C}$ and $61.95{ }^{\circ} \mathrm{C}$. The surface temperature of the fuel element plate is close to the saturation temperature and of course the nucleate boiling has begun, so that the cooling flow rate entering the reactor core with a value of $50 \mathrm{~kg} / \mathrm{s}$ is not able to cool the reactor core. The surface temperature of the fuel element plate starts to decrease lower than the saturation temperature if the cooling flow rate is greater than $65 \mathrm{~kg} / \mathrm{s}$, when the surface temperature of the fuel element is 96.65 ${ }^{\circ} \mathrm{C}$ and the cooling temperature is at the corresponding position $54.38{ }^{\circ} \mathrm{C}$ are obtained.

\section{ACKNOWLEDGEMENT}

Thank you to the Applied Nuclear Science and Technology Center - BATAN for funding assistance through DIPA in 2017. The author also wishes to thank Mr. P. Ilham Yazid for his contribution to this research activity in the supply of data from neutron calculations.

\section{REFERENCES}

1. Suwarno H. Development of TRIGA Fuel Fabrication by Powder Technique. Atom Indonesia. 2014. 40(3): 113-119.

2. Hampel G, The Importance of TRIGA Reactors, on Behalf of the European TRIGA community. 9th.Johannes Gutenberg-Universitat Mainz D-55099. 2010.

3. Basuki P, Yazid PI, Suud Z, Desain Neutronik Konversi Elemen Bakar Tipe Pelat Pada Teras Reaktor TRIGA 2000 Bandung. Jurnal Sains dan Teknologi Nuklir Indonesia. 2014. 15(2): 69-79.

4. Van Den Berghe S, Leenaers A, Edgar K, Leo S. From High to Low Enriched Uranium Fuel in Research Reactors. Advances in Science and Technology. 2010. 73: 78-90. 
5. Mandala GA. Simulasi Modifikasi Reaktor TRIGA 2000 Bandung Dengan Bahan Bakar Jenis Pelat. Proseding Seminar Nasional VI Sumber Daya Manusia Teknologi Nuklir. Yogjakarta. 2010. pp.769- 774.

6. Mandala GA, Sihana, Harto AW. Termohidrolik Usulan Modifikasi Reaktor Nuklir TRIGA 2000 Bandung Dengan Bahan Bakar Jenis Pelat. Prosiding Seminar Keselamatan Nuklir. Jakarta. 2011. pp. $254-265$

7. Alfa SK, Hastuti EP, Widodo S, Nazar R. Analisis Konveksi Alam Teras Reaktor TRIGA Berbahan Bakar Tipe Pelat Menggunakan Coolod-N2. Tri Dasa Mega. 2015. 17(2): 67-78

8. Subekti M., Isnaini D, Hastuti EP. Analisis Kecepatan Pendingin Dalam Elemen Bakar Tipe Plat Menggunakan Metode CFD Untuk Reaktor Riset RSG GAS, Tri Dasa Mega. 2013. 15(2); 67-76

9. Surbakti T, Pinem S, Suparlina L. Dynamic Analysis on the Safety Criteria of the Conceptual Core Design in MTR-type Research Reactor. Atom Indonesia. 2018. 44(2); 89 $-97$

10. Suparlina L, Surbakti T. Analisis Pola Manajemen Bahan Bakar Teras Reaktor Riset Tipe MTR. Tri Dasa Mega. 2014. 16(2): 88-99

11. Gharib M, Arkani M, Hossnirokh A. Design and apllication of MTR fuel assemblies in new proposed inverted mode. Nuclear Engineering and Design. 2010. 240: 2981-2987. 